\title{
PENGAWETAN ALAMI BERBAHAN DASAR SISIK IKAN PADA BUAH TOMAT HASIL PERTANIAN KELOMPOK TANI WORI
}

\author{
Inneke Fenny Melke Rumengan ${ }^{1)}$, Edy Lengkong ${ }^{2)}$, Aldian Hein Luntungan ${ }^{3)}$ Grace Debbie Kandou $^{4)}$ \\ ${ }^{1}$ Fakultas Perikanan dan Ilmu Kelautan, Universitas Samratulangi Manado \\ 2 Fakultas Pertanian Universitas Samratulangi Manado \\ ${ }^{3,4}$ Fakultas Kesehatan Masyarakat, Universitas Samratulangi Manado \\ Email: ${ }^{1}$ innekerumengan@unsrat.ac.id
}

\begin{abstract}
Abstrak
Desa Wori khususnya kelompok Tani Wori merupakan salah satu desa yang memiliki potensi dibidang pertanian. Selain potensi yang dimiliki ada beberapa permasalah yang dihadapi diantaranya permasalah pasca panen, seperti cepat membusuknya hasil produksi pertanian hortikultura. seperti buah tomat. Tomat dengan kandungan airnya yang tinggi memilki masa simpan cukup singkat bila tidak diberikan perlakuan. Sisik ikan dapat diolah menjadi senyawa yang memiliki potensi untuk dikembangkan sebagai pengawet alami. Pelaksanaan kegiatan ini berlokasi di Desa Wori, Kabupaten Minahasa Utara. Aplikasi produk pengawet alami diuji cobakan pada buah tomat yang dikelompokan menjadi 3 kelompok yaitu, kelompok tanpa perlakuan (kontrol), kelompok dengan pemberian kitosan, dan kelompok dengan nanokitosan. Observasi dilakukan pada hari ke-1, 3, 6 dan 9 setelah perlakuan diberikan, kemudian dilakukan analisis kadar airnya. Hasil kegiatan menunjukkan bahwa kelompok dengan pemberian kitosan dan nanokitosan dapat disimpan lebih lama sampai lebih dari 9 hari pada suhu ruang, sedangkan kelompok tomat kontrol hanya bertahan $<7$ hari, terlihat dengan mengerutnya permukaan buah tomat karena proses respirasi yang meningkatkan kadar air, sehingga mempercepat pembusukan. Kadar air buat tomat dengan kitosan dan nanokitosan masing-masing $88.67 \pm 6.42 \%$ dan $88.66 \pm 3.05 \%$, sedangkan tomat kontrol $94.66 \pm 3.05 \%$. Dengan demikian, pemberian kitosan dan nanokitosan dapat menjadi solusi bagi kelompok tani untuk mendapatkan produk yang lebih lama tingkat kesegarannya. Hasil pelaksanaan kegiatan ini membuka peluang peningkatan pendapatan petani serta pemanfaatan limbah sisik ikan untuk peningkatan kualitas produk pertanian.
\end{abstract}

Kata kunci : sisik ikan, kitosan, nanokitosan, tomat, desa Wori

\begin{abstract}
Wori village, especially the Wori Farmer group, is one of the villages that has the potential in agriculture. In addition to the potential possessed, there are several problems faced, including postharvest problems, such as the rapid decay of horticultural agricultural products such as tomatoes. Tomatoes with high water content have a short shelf life if not treated. Fish scales can be processed into compounds that have potential to be developed as natural preservatives. This implementation are located in Wori Village, North Minahasa. The application of natural preservative products was tested on tomatoes which is divided into 3 groups. They are the group without treatment (control), the group with the administration of chitosan, and the group with nanocitosan. Observations were made on days 1, 3, 6 and 9 after the treatment was given, then the water content analysis was carried out. The results showed that the group with chitosan and nanocitosan can be stored for more than 9 days at room temperature, while the control tomato group only lasted $<7$ days, seen by shrinking the surface of the tomato due to the respiration process which increases the water content. Water content for tomatoes with chitosan and nanocitosan were $88.67 \pm 6.42 \%$ and $88.66 \pm 3.05 \%$ respectively, while the control tomatoes were $94.66 \pm 3.05 \%$. Giving chitosan and nanocitosan can be a solution for farmer groups to get a product that has a longer level of freshness. The results of the implementation can open
\end{abstract}


opportunities for increasing farmers' income and the utilization of fish scales for improving the quality of agricultural products.

Keywords: fish scale, chitosan, nanochitosan, tomatoes, Wori village

\section{PENDAHULUAN}

Kondisi topografi serta tanah yang subur di Desa Wori, Kecamatan Wori, Kabupaten Minahasa Utara, membuat daerah ini menjadi salah satu kontributor hasil pertanian yang cukup produktif. Salah satu komoditi pertanian yang memberikan sumbangsi terbesar dalam produksi pertanian ialah buah tomat. Sekitar $40 \%$ peduduk di desa ini berprofesi sebagai petani (Djamaludin, 2016). Namun, permasalahan yang sering dihadapi petani di Desa Wori sama halnya dengan permasalahan petani pada umumnya yaitu proses pembusukan hasil pertanian yang cepat selama masa penyimpanan. Kelompok Tani Wori mengalami kesulitan saat harus menyimpan hasil tani seperti tomat yang belum terjual. Proses pembusukan yang cepat membuat sebagian besar petani mengalami kerugian. Hal ini disebabkan karena tomat memiliki kadar air yang tinggi sehingga menyebabkannya cepat rusak (Johansyah et al., 2014). Penanganan pasca panen merupakan suatu upaya yang perlu di perhatikan agar tingkat kesegaran produk dapat dipertahankan hingga dibeli konsumen.

Beberapa upaya yang biasanya dilakukan untuk mengatasi hal di atas terkadang beresiko dan memerlukan biaya tambahan. Metode pengawetan yang sering diterapkan antara lain pendinginan, pembungkusan menggunakan polietilen dan penambahan bahan kimia. Cara ini cukup mahal apabila diterapkan pada petani atau pedagang kecil. Disamping itu penggunaan bahan kimia kurang aman bagi kesehatan untuk buah tanpa kupas dan dapat mencemari lingkungan untuk buah kupas. Oleh karena itu penggunaan pengawet alami yang aman perlu diterapkan pada produk pertanian pasca panen yang mudah rusak seperti tomat.

Pemanfaatan limbah sisik ikan sebagai bahan baku pembuatan pengawet alami dapat menjadi salah satu solusi untuk mengatasi masalah ini. Sisik ikan merupakan limbah perikanan dengan jumlah yang melimpah di Sulawesi Utara yang terkenal dengan wisata kuliner makanan laut. Sisik ikan yang merupakan produk samping (by product) hingga saat ini belum dimanfaatkan secara optimal dan dibuang sebagai limbah (Nur'aenah, 2013, Rumengan et al., 2018). Padahal kandungan kitin di dalam sisik ikan memiliki potensi yang cukup menjanjikan untuk dikembangkan. Kandungan kitin dalam sisik ikan telah dikaji sebelumnya oleh Rumengan et al (2017) yang dapat dioptimalisasi menjadi senyawa kitosan melalui proses deasetilasi.

Kitosan merupakan salah satu senyawa yang mengandung antimikroba sehingga dapat digunakan sebagai pengemas produk segar (Rumengan et al, 2018). Meng et al (2010) melaporkan bahwa aplikasi pasca panen dari penyalut kitosan memiliki pengaruh kontrol yang baik terhadap kerusakan buah pasca panen. Kitosan juga dilaporkan dapat memperpanjang daya awet produk segar, karena memiliki aktifitas antimikroba yang dapat menghambat pertumbuhan mikroorganisme perusak dan memiliki karakter pelapis yang baik untuk meminimalkan interaksi produk dengan lingkungannya (Kim, 2011). Potensi molekuler kitosan jika dieksploitasi dengan penerapan nanoteknologi akan menghasilkan suatu inovasi dalam pengembangan bioindustri, karena nilai tambah kitosan sebagai biomaterial dapat dimaksimalkan.

Penerapan kitosan dan nanokitosan diharapkan dapat meningkatkan masa simpan 
dari buah tomat yang merupakan salah satu komoditi hasil pertanian kelompok Tani Wori. Pelaksanaan kegiatan pengabdian ini meskipun masih dalam tahap introduksi, diharapkan dapat membuka peluang terhadap penggunaan pengawet alami berbahan dasar sisik ikan yang aman dan ramah lingkungan. Kedepannya pengawet alami berbahan baku sisik ikan bisa diproduksi dalam skala industri, sehingga dapat digunakan secara berkala oleh petani setempat.

\section{METODE PELAKSANAAN}

Pelaksanaan kegiatan dilakukan pada bulan Maret - Mei 2019 di desa Wori kecamatan Wori kabupaten Minahasa utara. Pelaksanaan kegiatan pengabdian ini diantaranya ialah pembuatan larutan kitosan dan nanokitosan dari sisik ikan dan sosialisasi produk pada kelompok tani serta pengaplikasiannya sebagai pengawet alami pada hasil pertanian. Hasil pertanian yang digunakan sebagai sampel ialah buah tomat yang merupakan salah satu komoditi terbesar di desa ini.

\section{Pembuatan kitosan dan nanokitosan}

Preparasi kitosan sisik ikan mengacu pada Suptijah et al (1992) yang telah dimodifikasi, dan dimulai dengan ekstraksi kitin seperti yang dilaporkan oleh Rumengan et al ( 2017). Kitosan diperoleh dengan deasetilasi kitin dengan menambahkan $\mathrm{NaOH}$ $40 \%$ (1:10), lalu dipanaskan pada suhu 100$110 \mathrm{oC}$ selama 1 jam. Padatan yang diperoleh dicuci dengan air destilasi sampai $\mathrm{pH}$ netral sebelum dikeringkan di bawah sinar matahari. Kitosan yang diperoleh ditimbang dan disimpan pada suhu kamar. Preparasi nanokitosan menggunakan metode gelas ionik dengan homogenizier $2000 \mathrm{rpm}$ yang mengacu pada metode paten dari Rumengan et al (2018).

\section{Sosialisasi dan pembagian kuisioner}

Kegiatan sosialisasi dilakukan dengan menggunakan metode diskusi dua arah. Topik diskusi terkait permasalahan dalam pertanian serta manfaat dan proses pembuatan pengawet alami kitosan dari sisik ikan. Instrument yang digunakan dalam sosialisasi berupa brosur dan sampel produk kitosan dan nanokitosan. Adapun Intrument lainnya berupa kuisioner yang berisikan pertanyaan-pertanyaan tentang karakteristik dari masing-masing anggota kelompok tani.

Aplikasi kitosan dan nanokitosan pada buah tomat

Pengaplikasian kitosan dan nanokitosan sebagai pengawet alami dilakukan pada buah tomat yang dibagi menjadi 3 kelompok yaitu kelompok yang tidak diberikan perlakuan (kontrol), kelompok yang diberikan larutan kitosan $1 \%$ sebagai pembanding dan kelompok yang diberikan larutan nanokitosan. Pengamatan dilakukan pada hari ke-1, 3, 6, dan hari ke-9 setelah perlakuan diberikan. Kondisi penyimpanan berada pada suhu ruang. Pengamatan dilakukan terhadap perubahan struktur fisik tomat dan nilai kadar air. Analisis kadar air dilakukan di Laboratorium lanjutan MIPA Unsrat.

\section{HASIL DAN PEMBAHASAN Karakteristik kelompok Tani Wori}

Berdasarkan data dari karakteristik responden yang diperoleh melalui pengisian kuisioner, diketahui kelompok Tani Wori sebagian besar berjenis kelamin perempuan $(57.1 \%)$ dengan umur $>=30$ tahun $(85.7 \%)$. Ratarata tingkat pendidikan dari anggota kelompok Tani Wori ialah lulusan sekolah menegah atas (57.1\%). Namun, status ekomomi sebagian besar masih sangat jauh dari upah minimum pekerja. Pendapatan perbulan dari kebanyakan anggota tani masih < Rp.1.500.000 yaitu sebanyak 71.4\%. Status kepemilikan lahan ialah berstatus pemilik (42.9\%) dan penggarap (42.9\%). Hanya $14.3 \%$ anggota tani yang menyewa lahan pertanian untuk bercocok tanam, seperti tersaji pada Tabel 1 . 
Tabel 1. Karakteristik responden kelompok Tani Wori

\begin{tabular}{|c|c|c|c|}
\hline \multicolumn{2}{|c|}{ Karakteristik Responden } & Jumlah & (\%) \\
\hline \multirow{2}{*}{ Jenis kelamin } & Laki-Laki & 3 & 42.9 \\
\hline & Perempuan & 4 & 57.1 \\
\hline \multicolumn{2}{|c|}{ Total } & 7 & 100 \\
\hline \multirow[t]{2}{*}{ Umur } & $<30$ tahun & 1 & 14.3 \\
\hline & $>=30$ tahun & 6 & 85.7 \\
\hline \multicolumn{2}{|c|}{ Total } & 7 & 100 \\
\hline \multirow{3}{*}{ Pendidikan } & SD & 2 & 28.6 \\
\hline & SMP & 1 & 14.3 \\
\hline & SMA & 4 & 57.1 \\
\hline \multicolumn{2}{|c|}{ Total } & 7 & 100 \\
\hline \multirow[t]{2}{*}{ Penghasilan per bulan } & $<$ Rp. 1.500 .000 & 5 & 71.4 \\
\hline & $>=$ Rp. 1.500 .000 & 2 & 28.6 \\
\hline \multicolumn{2}{|c|}{ Total } & 7 & 100 \\
\hline \multirow{3}{*}{ Status kepemilikan lahan } & Pemilik & 3 & 42.9 \\
\hline & Penyewa & 1 & 14.3 \\
\hline & Penggarap & 3 & 42.9 \\
\hline \multicolumn{2}{|c|}{ Total } & 7 & 100 \\
\hline
\end{tabular}

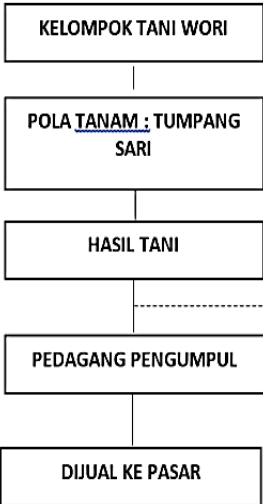

\section{Gambar 1. Alur penjualan kelompok Tani Wori}

Pada Gambar 1 menjelaskan alur penjualan kelompok Tani Wori. Kelompok tani ini memiliki jenis pola tanam tumpang sari, dimana dalam satu lahan ditanami berbagai macam tanaman. Hal tersebut dilakukan agar lebih efisien dan hasil tani bisa lebih bervariasi. Hasil tani yang diperoleh, dikumpulkan dan dijual ke pedagang pengumpul sebelum akhirnya dijual ke pasar tradisional. Hasil tani yang belum terjual, biasannya disimpan sampai bisa terjual. Tomat yang merupakan salah satu hasil tani kelompok ini biasanya memiliki masa simpan maksimal sampai 7 hari penyimpanan di suhu ruang.

\section{Penanaman bibit tomat pada lahan pertanian}

Kegiatan penanaman bibit tomat dilakukan secara tradisional. Pertama-tama dipersiapkan tempat persemaian terlebih dahulu. Benih yang berupa biji harus disemaikan menjadi bibit tanaman. Langkah ini diperlukan karena benih yang baru tumbuh memerlukan perlakuan yang berbeda dengan tanaman yang telah tumbuh besar. Tujuan penyemaian benih adalah untuk mengurangi kematian akibat tanaman yang belum siap dengan kondisi lapangan, serta melindunginya dari cuaca ataupun gangguan lainnya. (Yunus, 2018). Kegiatan dilakukan di lahan pertanian kelompok tani Wori di desa Wori. Bibit tomat yang digunakan berjumlah 1000 bibit dengan kualitas terbaik.

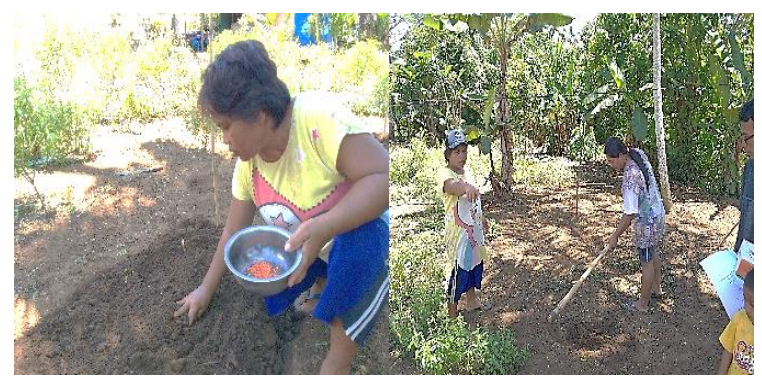

Gambar 2. Anggota kelompok tani sedang menanam bibit tomat di lahan pertanian

\section{Pembuatan kitosan dan nanokitosan dari limbah sisik ikan}

Kitosan yang dihasilkan berupa bubuk putih dengan berat $51 \mathrm{gr}$ dari bahan dasar sisik ikan sebanyak $1 \mathrm{Kg}$. Kitosan diperoleh melalui proses deasetilasi kitin. Kitin yang diekstraksi dari sisik ikan telah mengalami proses penghilangan protein (deproteinasi) dan mineral (demineralisasi). Modifikasi kitosan menjadi nanokitosan dilakukan menggunakan homogenizier dengan kekuatan $20.000 \mathrm{rpm}$.

Larutan kitosan dan nanokitosan berwarna bening dalam bentuk suspensi seperti terlihat pada Gambar 2. Larutan tersebut kemudian dimasukkan dalam botol spray dan diberi label untuk diaplikasikan pada tomat hasil pertanian kelompok tani Wori. 


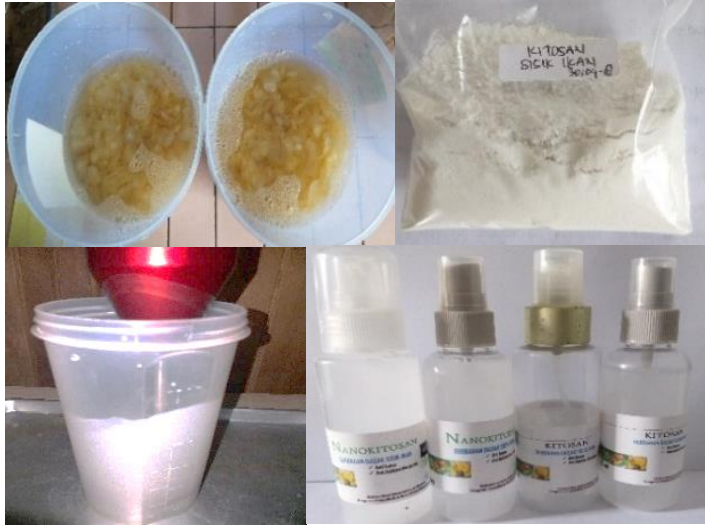

Gambar 3. Proses pembuatan kitosan dan nanokitosan

\section{Sosialisasi serta aplikasi produk kitosan dan} nanokitosan pada buah tomat

Sosialisasi tentang produk kitosan dan nanokitosan dilakukan secara dua arah. Kegiatan sosialisasi dihadiri oleh semua anggota kelompok Tani Wori. Instrumen tambahan yang digunakan dalam sosialisasi berupa brosur yang berisikan informasi pembuatan serta manfaat yang dihasilkan dari produk pengawet ini. Adapun pertanyaan-pertanyaan dari petani yang dilontarkan dalam diksusi yaitu terkait pengawetan produk pertanian pasca panen dan solusi terhadap hama yang menganggu tanaman.

Masalah yang sering dialami petani umumnya tentang hasil tani seperti buah tomat yang rusak akibat lamanya penyimpanan. Hal ini sejalan dengan fakta bahwa sepertiga produk hortikultura di dunia seperti tomat tidak dapat dikonsumsi karena rusak selama penyimpanan (Fitradesi, 2000).

Setiap anggota kelompok diberikan kesempatan untuk melakukan simulasi cara menggunakan larutan kitosan dan nanokitosan pada buah tomat. Aplikasi produk pengawet ini dilakukan dengan tujuan agar tomat yang belum terjual tidak cepat mengalami pembusukan. Hasil pertanian tomat yang melimpah, membuat tomat kadang kala tidak terjual semuanya. Kondisi ini menjadikan petani mengalami kerugian karena sisa tomat yang telah membusuk sebelum terjual. Penggunaan mesin pendingin seperti kulkas dinilai belum tepat untuk menyimpan tomat karena memberikan tambahan biaya seperti pengeluaran biaya listrik. Disamping itu, ruang penyimpanan yang terbatas membuat tidak semua tomat bisa disimpan dalam kulkas. Untuk itu, diberikan solusi berupa pengawet alami kitosan dan nanokitosan dengan bahan dasar yang mudah diperoleh yaitu sisik ikan dan aplikasinya yang mudah, karena hanya disemprot di permukaan tomat. Pengaplikasian produk pengawet ini pada buah tomat dilakukan oleh anggota kelompok tani selama 9 hari waktu observasi.

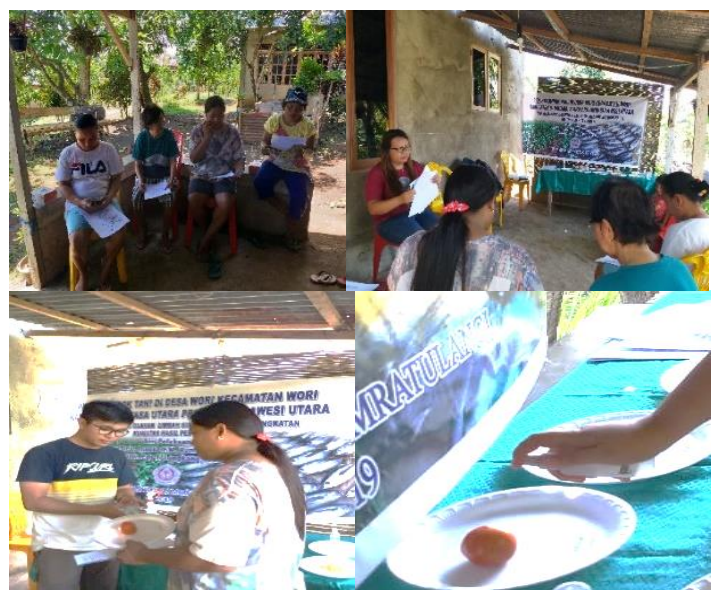

Gambar 4. Sosialisasi penggunaan produk kitosan dan nanokitosan (atas); aplikasi produk pada buah tomat (bawah)

\section{Hasil pengamatan buah tomat yang diberikan} kitosan dan nanokitosan

Pengamatan buah tomat dilakukan secara berkala, yaitu pada hari ke-1,3,6,dan 9 setelah perlakuan diberikan. Pada Gambar 4, terlihat perubahan warna dan tekstur dari buah tomat selama masa penyimpanan. Pada kelompok kontrol dimana tomat tidak diberikan perlakuan, dari hari ke-1sampai hari ke-3 tidak terlihat perubahan tekstur yang signifikan. Kondisi tomat berubah pada hari ke-6 masa penyimpanan, 
dimana sudah terlihat area tomat yang mengkerut. Pada hari ke-9, area tomat yang rusak bertambah menjadi dua bagian seperti terlihat pada Gambar 4. Hal ini sesuai dengan pendapat dari Rudito (2005) bahwa buah tomat yang dipanen setelah timbul warna merah $10 \%$ sampai dengan $20 \%$ hanya tahan disimpan maksimal selama 7 hari pada suhu kamar. Kerusakan ini akan terjadi apabila tidak ada perlakuan pada penyimpanannya. Buah yang telah dipanen masih melakukan proses metabolisme dan respirasi yang menyebabkan perombakan zat-zat nutrisi pada buah dan mengakibatkan terjadinya proses kemunduran sehingga buah cepat rusak.

Hal berbeda ditunjukkan pada tomat yang diberikan perlakuan kitosan dan nanokitosan. Pada kelompok ini, tidak terlihat perbedaan tekstur seperti pada kelompok kontrol dari hari ke-1 sampai hari ke-9. Perubahan yang terjadi hanya dari warna buah tomat yang semakin merah. Warna merupakan sifat produk pangan yang dapat dipandang sebagai sifat fisik (obyektif) dan sifat organoleptik (subyektif) (Lathifa, 2013). Perubahan warna ini merupakan hal yang lumrah karena disebabkan oleh proses pematangan buah tomat.

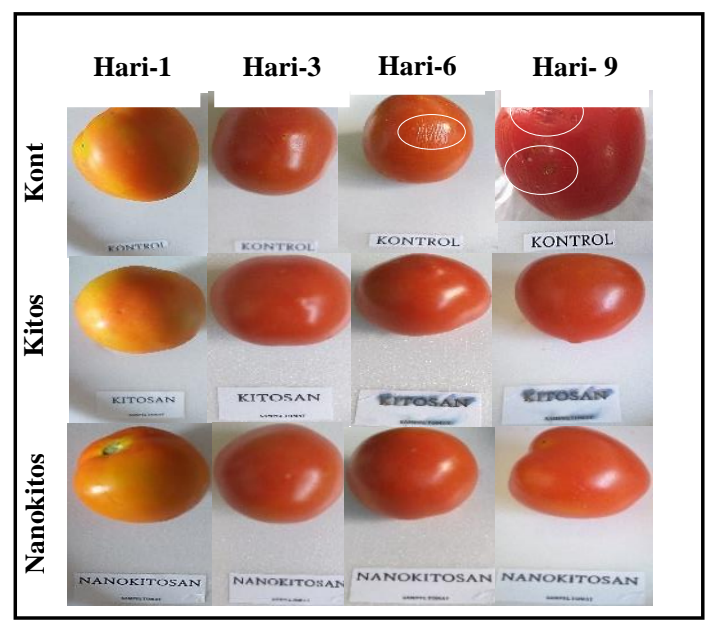

\section{Gambar 5. Penampakan tomat selama 9 hari penyimpanan dalam suhu ruang}

Tabel 2. Hasil analisis kadar air tomat hari ke-9 masa penyimpanan

\begin{tabular}{cccccc}
\hline & & \multicolumn{3}{c}{ Ulangan } & Rata-rata \\
\cline { 3 - 5 } No & Sampel & 1 & 2 & 3 & $(\%)$ \\
\hline 1. & Kontrol & 92 & 94 & 98 & $94.66 \pm 3.05$ \\
\hline 2. & Kitosan & 84 & 96 & 86 & $88.67 \pm 6.42$ \\
\hline 3. & Nanokitosan & 92 & 88 & 86 & $88.66 \pm 3.05$ \\
\hline
\end{tabular}

Berdasarkan hasil analisis kadar air buah tomat seperti yang tersaji pada Tabel 2, menunjukkan bahwa tomat yang diberikan perlakuan kitosan dan nanokitosan memiliki kadar air yang lebih rendah dibandingkan dengan kelompok kontrol yaitu $88.67 \pm 6.42 \%$ dan $88.66 \pm 3.05 \%$ secara berurutan. Kelompok kitosan dan nanokitosan tidak menunjukkan perbedaan yang signifikan terhadap kadar air buah tomat selama masa penyimpanan. Itu berarti ukuran partikel nano diduga tidak terlalu mempengaruhi kadar air buah tomat selama masa penyimpanan.

Kenaikan kadar air buah tomat pada kelompok kontrol terjadi akibat adanya produksi air metabolit hasil proses respirasi (Nugraheni, 2017). Respirasi adalah suatu metabolisme yang memerlukan oksigen untuk pembakaran senyawa makromolekul seperti karbohidrat, lemak, protein yang menghasilkan $\mathrm{CO} 2$, air dan sejumlah elektron-elektron (Winarno dan Aman, 1981). Laju respirasi dari suatu buah merupakan indikator yang baik bagi aktivitas metabolik jaringan. Oleh karena itu, respirasi dapat digunakan sebagai petunjuk terhadap potensi umur simpan. Kecepatan respirasi yang tinggi biasanya berhubungan dengan tingkat umur simpan yang pendek (Goldsmidt 1997). Kandungan air yang tinggi membuat tomat mudah ditumbuhi jamur dan bakteri.

Kitosan dan nanokitosan sebagai pengawet alami diduga melapisi perumukaan tomat sehingga memperlambat proses respirasi yang berdampak terhadap kerusakan mutu tomat. Selain itu, sifat antibakteri kitosan yang berasal dari struktur polimer dengan kandungan gugus amin bermuatan positif, dapat berinteraksi 
dengan muatan negatif suatu molekul misalnya protein dari mikroba sehingga mampu memperpanjang masa simpan tomat.

\section{KESIMPULAN}

Meningkatnya masa simpan tomat melalui penggunaan produk kitosan dan nanokitosan dapat mengatasi masalah kerugian kelompok Tani Wori tekait sisa tomat yang cepat membusuk. Dengan demikian, hasil pelaksanaan kegiatan ini membuka peluang peningkatan pendapatan petani setempat.

\section{UCAPAN TERIMA KASIH}

Kegiatan ini terselenggara atas bantuan dana dari PNBP Univesitas Sam Ratulangi Manado tahun anggaran 2019 dengan skema Pengabdian Kemitraan Masyarakat (PKM)

\section{REFERENSI}

Djamaludin, R. 2016. Kabupaten Minahasa Utara :Profil, Sejarah, dan Potensi Unggulan Desa. LPPM Unsrat : Manado

Fitradesi. 2000. Pelapisan Chitosan Pada Buah Salak Pondoh (Sallaca edulis Reinw). Sebagai Upaya Memperpanjang Umur Simpan dan Kajian Sifat Fisiknya Selama Penyimpanan. Jurnal Teknologi Pertanian. 6 (2): 45-49

Goldsmidt EE. 1997. Ripening of citrus and other nonclimacteric fruit: a role for ethylene. Acta Hotict 463:335-340.

Johansyah, A., E. Prihastanti dan E. Kusdiyantini. 2014. Pengaruh plastik pengemas Low Density Polyethylene High Density Polyethlene \& Polipropilen (PP) terhadap penundaan kematangan buahtomat. Buletin Anatomi dan Fisiologi. 22(1) : 46-57.

Kim, S.W. 2011. Chitin, chitosan, oligosaccharides and their derivates. Ebook. USA : CRC Press

Lathifa H. 2013. Pengaruh Jenis Pati Sebagai Bahan Edible Coating dan Suhu Penyimpanan Terhadap Kualitas Buah
Tomat. (Skripsi). Malang (Indonesia): Universitas Islam Negeri Maulana Malik Ibrahim.

Meng, X., Yang, L., Kennedy, J.F., and Tian, S. (2010a). Effects of chitosan and oligochitosan on growth of two fungal pathogens and physiological properties in pear fruit. Carbohyd. Polym. 81 : 70-75.

Nungraheni,D., R.Endrasari dan I.Ambarsari. 2017. Perbedaan kualitas buah tomat hasil produksi screen house dan lahan terbuka selama penyimpanan. Balai Pengkajian Teknologi Pertanian Jawa Tengah pp:4953

Nur'aenah N. 2013. Ekstraksi dan Karakterisasi Kolagen dan Nanopartikel Kolagen dari Kulit Ikan Pari Sebagai Bahan Baku Kosmetik. Disertasi.Institut Pertanian Bogor.

Rumengan, I.F.M., P. Suptijah, S. Wullur, and A. Talumepa. 2017. Characterization of chitin extracted from fish scales of marine fish species purchased from local markets in North Sulawesi, Indonesia. IOP Conf. Series: Earth and Environmental Science. doi :10.1088/1755-1315/89/1/012028

Rumengan, I.F.M., P. Suptijah., N. Salindeho., S. Wullur., A. H. Luntungan. 2018. Nanokitosan dari sisik ikan: Aplikasinya sebagai pengemas produk perikanan. LPPM Unsrat. ISBN : 9786025242649

Rudito. 2005. Perlakuan Komposisi Gelatin dan Asam Sitrat Dalam Edible Coating Yang Mengandung Gliserol Pada Penyimpanan Tomat. Jurnal Teknologi Pertanian. Politeknik Pertanian Negeri Samarinda. Samarinda. Vol 6. No. 1: 1-6.

Winarno FG, Aman M. 1981. Fisiologi Lepaspanen. Jakarta: Sastra Hudaya.

Yunus,S. 2018.Cara menanam tomat dalam polybag. (online)https://alamtani.com/caramenanam-tomat/ diakses pada tanggal 18 Mei 2019 
ABADIMAS ADI BUANA

e-ISSN 2622-5719, p-ISSN 2622-5700

VOL. 03. NO. 1, 1 Juli 2019 